\title{
FINDING ORDER IN CALGARY's CASH CORNER: USING Legal PluRALISM TO CRAFT LEgal REMEDIES FOR Conflicts Involving Marginalized Persons in Public Spaces
}

\author{
JAMIE C.Y. LIEW*
}

Binners, book and magazine sellers, day labourers protestors, and sex workers are fixtures in our Canadian urban jungle that the law seeks to regulate. Legal responses to the existence of marginalized persons in public spaces have aimed at excluding them from public space. Much of the work employing legal pluralism as a lens through which we view our urban landscape focuses on the effect of the law on marginalized communities. The courts are increasingly being asked by marginalized communities to mediate conflicts arising in public spaces. This article analyzes this effect on marginalized communities and suggests that, in finding remedies, the courts should take guidance from ethnographic research using a legal pluralism lens.
Les binners, les vendeurs de livres et de revues, les manifestants journaliers et les travailleurs du sexe font tous partie du paysage urbain canadien, et le législateur cherche à les réglementer. Les réactions juridiques à la présence de personnes marginalisées dans les espaces publics ont cherché à les exclure de tout espace public. Une grande partie de l'effort de pluralisme juridique en tant que point de vue du paysage urbain cible l'effet de la loi sur les communautés marginalisées. Ces communautés demandent de plus en plus aux tribunaux de servir d'intermédiaire dans les conflits survenant dans les espaces publics. Cet article analyse cet effet sur les communautés marginalisées et propose que, dans leur recherche de solutions, les tribunaux s'inspirent $d u$ pluralisme juridique dans la recherche ethnographique.

\section{TABLE OF CONTENTS}

I. INTRODUCTION . . . . . . . . . . . . . . . . . . . . . . . . 606

II. CONFLICT IN OUR URBAN JUNGLES . . . . . . . . . . . . . . . . . 607

III. CASH CORNER . . . . . . . . . . . . . . . . . . . . . . . . . . . . 609

A. What is CASH CoRner? . . . . . . . . . . . . . . . . . 610

B. CONFLICTS BETWEEN COMMUNITIES

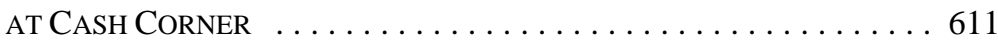

C. Legal TOOLS USED TO CONTROL PERSONS

AT CASH CORNER . . . . . . . . . . . . . . . . . . . . . . . . . . . . . 613

D. THE EfFECTS OF THE BYLAWS $\ldots \ldots \ldots \ldots \ldots \ldots \ldots \ldots \ldots \ldots$

IV. FINDING ORDER IN CASH CORNER . . . . . . . . . . . . . . . . . . . 614

A. THE SHORTCOMINGS OF LEGAL

RESPONSES SO FAR . . . . . . . . . . . . . . . . . 614

B. USING A LEGAL PLURALISM FRAMEWORK

TO VIEW CASH CORNER . . . . . . . . . . . . . . . . . . . . . 616

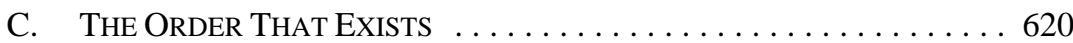

D. How Legal Pluralism Changes

DisCOURSE AROUND CASH CORNER . . . . . . . . . . . . . . . . 625

V. CONCLUSION ........................... 634

Assistant Professor, Faculty of Law, University of Ottawa. 


\section{INTRODUCTION}

Binners, book and magazine sellers, day labourers, protestors, and sex workers are fixtures in our Canadian urban jungle that the law seeks to regulate. Legal responses to the existence of marginalized persons in public spaces have aimed at excluding them from public space. As evidenced by recent cases, courts are increasingly mediating disputes over the use of civic space. ${ }^{1}$ So far, the law has not provided a durable solution to ongoing conflicts between marginalized communities in public spaces and those living nearby. ${ }^{2}$

Using the example of day labourers in downtown Calgary, the article argues that more imaginative and consultative remedies are necessary to provide more stable harmony in public spaces. ${ }^{3}$ Turning to the theory of legal pluralism, this article will posit that we look at marginalized persons in public spaces not as obstructions, nuisances, deviants, or random chaotic beings but as citizens who survive because there are common rules and norms by which they abide. This article will also point to ethnographic research on marginalized persons using informal economies in public spaces to illuminate the non-state imposed normative order that exists in public spaces. ${ }^{4}$

Much of the work employing legal pluralism as a lens through which we view our urban landscape focuses on the effect of the law on marginalized communities. For example, studies show how marginalized persons are excluded from public space through the enforcement of state law. This article extends the work of sociolegal scholars by exploring how legal pluralism can be employed in crafting remedies in courts. By appreciating that there is order amongst marginalized communities, courts can move away from a competing rights approach and fashion more fair and consultative remedies which include discussing how everyone can live together in public space.

Batty v Toronto (City), 2011 ONSC 6862, 108 OR (3d) 571 [Batty]; Victoria (City) v Adams, 2009 BCCA 563, 313 DLR (4th) 29 [Adams]; Canada (AG) v Bedford, 2013 SCC 72, [2013] 3 SCR 1101 [Bedford].

2 I use the terms conflict or dispute to characterize how marginalized persons in public spaces are being challenged by either law enforcement or the wider public such as pedestrians, business owners, and residents in a neighbourhood on their use of public space.

3 The term remedy is used in this article as relief given by legal institutions in the traditional or formal sense, while challenging the forms of the relief. In particular, the article aims to discuss whether remedies, rather than imposed, ordered, or granted by courts, can be crafted with the achievement of social harmony in a given conflict.

$4 \quad$ This article discusses persons congregating in public spaces but focuses on informal economies in public spaces. While there is little consensus on the definition of informal economy, I define it as employment that escapes taxation or regulation by governments. While informal economies can include criminal activity, this article focuses on work that is recognized as not inherently illegal itself. For the purposes of this article, informal economy, for example, does not include theft, sale of stolen goods, or sale of drugs. 


\section{Conflict in Our Urban Jungles}

Regulation of civic spaces has occurred as long as cities have. Ian Hoskins finds that regulation was "rationalised with reference to its democratic ends — of maintaining parks for the citizenry." ${ }^{5}$ The challenge however, is who embodies the citizenry. ${ }^{6}$

Conflicts have arisen in Canadian courts over the use of public space by panhandlers, ${ }^{7}$ squeegeers, ${ }^{8}$ sellers of printed material, ${ }^{9}$ and protestors. ${ }^{10}$ Three recent cases stemming from conflicts in urban public spaces raise questions of how civic space should be used. The first involves homeless persons in a "tent city” in Cridge Park in Victoria, British Columbia. They challenged the City's bylaws prohibiting the erection of temporary shelter while they slept in the park. ${ }^{11}$ The trial judge aptly described the conflict as: "an inevitable conflict between the need of homeless individuals to perform essential, life-sustaining acts in public and the responsibility of the government to maintain orderly, aesthetically pleasing public parks and streets."12

The Court of Appeal noted a number of findings of fact: (1) there were more than 1000 homeless in Victoria; (2) the city only had, at most, 326 shelter beds; (3) bylaws do not prohibit sleeping in public spaces but do prohibit taking up a temporary abode; and (4) being exposed to the elements without adequate protection is associated with some significant risks to health and to life. ${ }^{13}$ Relying on these findings, the Court concluded that prohibiting temporary shelters in public spaces seriously affected a person's section 7 Charter rights. ${ }^{14}$

Ian Hoskins, “'The Core of the City’: Public Parks, Respectability and Civic Regulation in Sydney” (2003) 5:1 National Identities 7 at 9.

Ibid at 10 :

Those who conformed to the dominant ideal of respectability encompassed in regulations ... were recognized as citizens. Those who did not were rhetorically excluded from the body corporate and, as such, also ran the risk of physical exclusion from the public spaces dedicated to "the people". Some, with their own expectations of right of access to public parks, challenged official representations of civility through the articulation of civic rights. Others, in particular, the homeless, prostitutes and urban gangs, laid claim to the parks through simple occupation.

In Federated Anti-Poverty Groups of British Columbia v Vancouver (City), 2002 BCSC 105, 40 Admin LR (3d) 159, the Court found that panhandling is not protected by the freedom of expression provision in the Charter (section 2(b)), does not violate the right to life, liberty, and security of the person under section 7, and does not violate section 15(1) by discriminating on the basis of poverty, social conditions, and personal characteristic of poverty).

In $R v$ Banks, 2007 ONCA 19, 84 OR (3d) 1, while the Court found that the impugned provisions in the Ontario Highway Traffic Act violated freedom of expression in section 2(b) of the Charter, the Court also held that the provisions are justified under section 1 of the Charter.

$9 \quad$ In Churchill v Greater Vancouver Transportation Authority, 2001 BCSC 572, 88 BCLR (3d) 364, the Court found that the policy of the transportation authority violated the freedom of expression of the petitioner who wanted to distribute political literature.

In Vancouver (City of) v Zhang, 2010 BCCA 450, 325 DLR (4th) 313, the Court found the City's effective ban on the use of a structure for political expression did not meet the minimal impairment requirement and therefore allowed practitioners of Falun Gong to continue their protest in front of the Chinese Consulate.

Adams, supra note 1.

Ibid at para 3.

Ibid at para 28.

Ibid; Canadian Charter of Rights and Freedoms, Part I of the Constitution Act, 1982, being Schedule B to the Canada Act 1982 (UK), 1982, c 11 [Charter]. 
Despite this, the decision only amounts to a right to sleep in a cardboard box. ${ }^{15}$ No positive rights were upheld, keeping the status quo.

The second example of conflicts in public spaces involves sex workers. ${ }^{16}$ Sex workers in public spaces are often in conflict with those in the community and the law. ${ }^{17}$ In Bedford, three sex workers sought a declaration that three provisions of the Criminal Code were unconstitutional pursuant to sections 7 and 2(b) of the Charter. ${ }^{18}$ The Criminal Code provisions prohibited a person from keeping a bawdy-house, from living on the avails of prostitution of another, and from communicating for the purpose of engaging in prostitution. ${ }^{19}$ The Supreme Court of Canada found the three impugned provisions unconstitutional. ${ }^{20}$ The Supreme Court disagreed with the Court of Appeal's finding that only two of the provisions were unconstitutional (communicating for the purpose of engaging in prostitution was saved by section 1 of the Charter), creating an inside-outside distinction where sex work taking place in "private" is protected by the Charter but sex work in public is not. ${ }^{21}$ The Supreme Court's decision effectively erases any public-private distinction and leaves it to Parliament to decide whether there should be limits imposed on where and how prostitution may be conducted. ${ }^{22}$

As the last example, Occupy Toronto protestors encamped in a public park in Toronto brought an application arguing the City's trespass notice infringed their freedom of expression under the Charter. ${ }^{23}$ While the Court found that the trespass notice violated the protestors' section 2 rights, the Court also held that "[t]he Charter does not permit the Protestors to take over public space without asking, exclude the rest of the public from enjoying their traditional use of space, and then contend that they are under no obligation to leave.”24 The notice was saved under section 1 of the Charter.

See Martha Jackman, “Charter Remedies for Socio-economic Rights Violations: Sleeping Under a Box?” in Justice Robert J Sharpe \& Kent Roach, eds, Taking Remedies Seriously (Canadian Institute for the Administration of Justice, 2010) 279; Sarah Buhler, "Cardboard Boxes and Invisible Fences: Homelessness and Public Space in City of Victoria v. Adams” Case Comment, (2009) 27:1 Windsor YB Access Just 209 at 210.

16 Bedford, supra note 1.

17 The word "community" is used in this sense to refer to different groups of people in a neighbourhood, such as residents, business owners, pedestrians, and park users. It is a general term meant to include anyone that could use public space but may or may not be in agreement with or tolerant of how some people, like sex workers, are using public space.

The applicants allege that all three provisions infringe s. 7 of the Canadian Charter of Rights and

Freedoms by preventing prostitutes from implementing certain safety measures - such as hiring

security guards or "screening" potential clients - that could protect them from violent clients. The

applicants also allege that s. 213(1)(c) infringes s. 2(b) of the Charter, and that none of the

provisions are saved under s. 1.

See Criminal Code, RSC 1985, c C-46, ss 210, 212(1)(j), 213(1)(c).

Bedford, supra note 1 at para 164.

Bedford v Canada (AG), 2012 ONCA 186, 109 OR (3d) 1 at paras 5-6.

Bedford, supra note 1 at para 165; see e.g. Mike Blanchfield, "Prostitution bill hearings to begin in special summer parliament session," The Globe and Mail (6 July 2014), online: <www.the globeandmail.com>. The House of Commons Standing Committee on Justice and Human Rights held a special session in July 2014 to hear from witnesses regarding the government's new prostitution bill in response to the Supreme Court of Canada's ruling to strike down Canada's previous prostitution law. The hearing reflected the various views on how Canada should proceed on the issue of criminalization of prostitution. 
Civic spaces are the centre of these conflicts because of the open-access nature of the space. ${ }^{25}$ The increased attention to the use of sidewalks, streets, and parks have raised questions about whether there should be more or less social control, and how public spaces are to be used. Further, when these conflicts manifest in the courtroom, how should the court respond to parties who are engaged in prolonged conflicts in their community?

Legal scholarship has focused on the effects state laws have on persons congregating in public spaces and how to challenge or repeal these laws. ${ }^{26}$ Scholars acknowledge that resisting or challenging state laws is necessary but not sufficient to undermine the various forms of exclusion and marginalization of persons on the street. ${ }^{27}$ This article attempts to extend the work of scholars who have mapped normative orders in public streets. I argue that recognizing norms of marginalized communities in public space can change the discourse regarding appropriate legal remedies to conflicts in civic spaces. Courts can rethink what makes space orderly with a legal pluralism lens.

\section{CASH CORNER}

The article situates the conversation about using a legal pluralism framework to design remedies for conflicts in public spaces in the example of Cash Corner in Calgary. ${ }^{28}$ This case study is used for two reasons. First, Cash Corner is a durable fixture in public space, having existed for over 50 years; it is not fleeting or temporary. Second, this article focuses on how we can share public space in Canada. Cash Corner provides a local example in a growing urban setting where homelessness is on the rise. ${ }^{29}$

Robert C Ellickson, “Controlling Chronic Misconduct in City Spaces: Of Panhandlers, Skid Rows, and Public-Space Zoning” (1996) 105 Yale LJ 1165 at 1168. Public spaces are the commons or "classic sites for 'tragedy.",

26 See e.g. Nicholas Blomley, Rights of Passage: Sidewalks and the regulation of public flow (Oxon, UK: Routledge, 2011); Don Mitchell, "The Annihilation of Space by Law: The Roots and Implications of Anti-homeless Laws in the United States” in Nicholas Blomley, David Delaney \& Richard T Ford, eds, The Legal Geographies Reader: Law, Power, and Space (Oxford: Blackwell, 2001) 6.

$27 \quad$ Marie-Eve Sylvestre, "Disorder and Public Spaces in Montreal: Repression (and Resistance) Through Law, Politics, and Police Discretion” (2010) 31:6 Urban Geography 803 at 819; see Bill C-36, An Act to amend the Criminal Code in response to the Supreme Court of Canada decision in Attorney General of Canada v. Bedford and to make consequential amendments to other Acts, 2nd Sess, 41st Parl, 2014, (as passed by the House of Commons 6 October 2014). The Canadian government's new prostitution bill also reflects that while laws may be struck down, different versions that may restrict certain activities in public space may be crafted again.

28 To date there is a dearth of ethnographic study of persons frequenting Cash Corner in Calgary. Thus, much of the information garnered around Cash Corner comes from news reports or tangentially through research on homeless persons in Calgary. The author hopes that this piece will be a stepping stone to future in depth study of Cash Corner in Calgary.

29 Steven Persaud, Lynn McIntyre \& Katrina Milaney, "Working Homeless Men in Calgary, Canada: Hegemony and Identity” (2010) 69:4 Human Organization 343 (“Calgary's homeless population has grown substantially in the last several years, despite boasting one of the strongest economies in the world" at 343); see also Calgary Economic Development, Calgary: A Global Scorecard on Prosperity, May 2009, online: <www.calgaryeconomicdevelopment.com/sites/default/files/pdf/research/reports/ special_research/globalScorecardProsperity.pdf >; Gordon Laird, Shelter: Homelessness in a growth economy - Canada's 21st century paradox (Calgary: Sheldon Chumir Foundation for Ethics in Leadership, 2007), online: <www.chumirethicsfoundation.ca/files/pdf/SHELTER.pdf> ("Calgary's homeless population grew 740 per cent between 1994 and 2006, for example, an average 40 per cent increase in homelessness every two years" at 4); see also Michael L Shier, Marion E Jones \& John R Graham, "Social Communities and Homelessness: A Broader Concept Analysis of Social Relationships and Homelessness" (2011) 21:5 J Human Behavior in the Social Environment 455, discussing the difficulties of sharing accommodations in Calgary despite the necessity to do so because of rising housing costs, and also discrimination and stereotypes placed on homeless people by landlords and employers. 


\section{A. What IS CASH CoRner?}

Cash Corner is a fifty-year-old public institution in downtown Calgary, Alberta where day labourers ${ }^{30}$ wait to be hired for cash. ${ }^{31}$ One bylaw officer said, "There seems to be an industry expectation to be able to pick people up." ${ }^{\text {„2 }}$ There are myriads of people at Cash Corner. Nearly half of Calgary's homeless population is working. ${ }^{33}$ Some use Cash Corner to supplement their earnings, suggesting they are not earning a living wage. ${ }^{34}$ Others are unable to find stable and regular work, and some are migrants looking for a piece of the oil boom. ${ }^{35}$ People who frequent Cash Corner appear on the sidewalk at approximately 6 a.m. ${ }^{36}$ In 2006, one reporter found:

Every 10 to 20 minutes, a truck or car pulls up and several men crowd around trying to snag work for the day. The employer describes the job — usually construction, moving or landscaping — as well as the pay — usually at least $\$ 12$ an hour or about $\$ 100$ a day. Sometimes steel-toed boots are needed, sometimes it's just a willingness to do hard labour.... The pay comes in cash and sometimes a meal, and the work comes the way the men and employers like it — no ties and no commitments, and usually no records and no taxes. ${ }^{37}$

Those using the Corner use it to survive in a city they describe as increasingly expensive. ${ }^{38}$ As with other informal economies, Cash Corner exists as a "form of 'self-help" enabling marginalized persons to make a living when there is "regulatory slippage” offering

30 The author defines day labourers as those not formally employed and who will work for cash.

31 Calgary Herald, "Developers move in on jobseekers' corner" (18 December 2006), online: <www. canada.com/calgaryherald/news/story.html?id=87588a48-976e-4c05-a222-4ab1f1a356db $>$. Cash Corner is located between 12th and 13th Avenues, and Centre Street and 1st Street S.E. Before 1994, Cash Corner had a more visible location at the intersection of 1st Street and 12th Avenue S.W. The Corner was forced to move because the Westward Inn "was going upscale."

32 Suzanne Zwarun, "Mixed-use nixes Calgary day labour spot” Journal of Commerce (5 July 2006), online: <http://www.journalofcommerce.com/article/20060705700>; see also Marion E Jones, Michael L Shier \& John R Graham, "Social exclusion and self-esteem: The impact of the identity — bureaucracy nexus on employed people experiencing homelessness in Calgary, Canada” (2013) 29:2 Journal of Intl and Comparative Social Policy 134 ("[t]here exists a systemic dependence on a segment of the population to fill precarious employment opportunities (such as temporary, day labour, or part-time types of work), represented most visibly by employed persons experiencing homelessness, created by the very nature of how the economy functions” at 139).

33 Michael L Shier, Marion E Jones \& John R Graham, "Perspectives of Employed People Experiencing Homelessness of Self and Being Homeless: Challenging Socially Constructed Perceptions and Stereotypes” (2010) 37:4 J Sociology \& Social Welfare 13; Jacey D Payne, Day In, Day Out: Exploring the Experiences of the Homeless Working Poor in Calgary, Alberta (MA Thesis, University of Alberta Department of Sociology, 2013) [unpublished] at 9, online: University of Alberta Libraries <hdl. handle.net/10402/era.29902>; see also Persaud, McIntyre \& Milaney, supra note 29 (despite Calgary being ranked number one in the world in terms of economic strength and labour market attractiveness, there are increasing problems of homelessness and reports that many homeless are working homeless. In particular the authors state: "an increasing number of individuals who work but do not earn enough income to find and sustain housing, coupled with dramatically increasing numbers of people who are homeless or vulnerable to homelessness” at 344).

$34 \quad$ Persaud, McIntyre \& Milaney, ibid ("All individuals [interviewed] were working in some capacity, most often in casual, day-labour positions” at 345). See also Jeff Karabanow et al, "The Economics of Being Young and Poor: How Homeless Youth Survive in Neo-liberal Times” (2010) 37:4 J Sociology \& Social Welfare 39 ("[t]he vast majority of young people on the street are engaged in informal work. Yet, street youth are also involved in formal work in different ways" at 52 . The authors also state: “As such, formal and informal work continually intersect” at 54).

Persaud, McIntyre \& Milaney, ibid; see also Calgary Herald, supra note 31.

Calgary Herald, ibid.

Ibid.

Nicholas Kohler, “Condos Beat Cash” Maclean’s (9 April 2007) (EBSCO). One frequenter of the Corner stated the city is designed more for "people so rich they don't even know where the gas cap in their vehicle is”; Persaud, McIntrye \& Milaney, supra note 29 ("Calgary is an oil-driven city of one million people, showing rapid growth in population and economy over the past twenty years that coincides with the growth of the oil and gas sector" at 344). 
opportunities for persons to engage in creative ways to survive in a world where access to job opportunities are made for those who have privileged access to living space or amenities such as the Internet. ${ }^{39}$

\section{B. Conflicts BetWeen Communities AT CASH CoRneR}

While Cash Corner has existed for years, some are not shedding any tears at the prospect of "evicting” it from the neighbourhood. ${ }^{40}$ Calgary’s previous mayor, David Bronconnier was against the Corner, characterizing it as "illegal under-the-table work that gives Cash Corner its name, and the fact that workers usually don't pay taxes." ${ }^{\text {41 }}$ In 2005, the City was advised: "by finding a different site for the activity we could be seen to be aiding what is likely illegal vis a vis income tax and workers compensation laws." ${ }^{\text {"2 }}$ Businesses in the area are eager to remove Cash Corner from the block. For example, the Hotel Arts stated they invested a tremendous amount of money into the block and Cash Corner is impacting business because people perceive it is not safe. ${ }^{43}$ Building developers in the area have also lobbied for Cash Corner's removal. ${ }^{44}$

In February 2007, City council voted for City staff to draft a plan exploring the options of moving Cash Corner or regulating it. ${ }^{45}$ Alderman Diane Colley-Urquhart's position was that the City should "steer clear of the problem.”46 Cash Corner's Alderman, Madeleine King, said the City should get involved because of problems with garbage and public nuisances. According to her, “[i]t's a real problem for people working in the area and the business community and the development industry." 47

In March 2008, the City proposed to have the Corner relocated a few blocks away. ${ }^{48}$ The new location, it was argued, "will have minimal impact on the community and the needs of

Sheila R Foster, “Urban Informality as a Commons Dilemma” (2009) 40:2 U Miami Inter-Am L Rev 261 at 264-65; see also Jones, Shier \& Graham, supra note 32 at 138-39 where the authors write:

The nature of the job market has changed dramatically over the last 20 years. Most employment opportunities are listed online and applications are also to be completed online. This creates a barrier for homeless people as they may not have easy access to the internet, to a computer where they can create and store their resume and letters of application, or even possess the skills to utilize this technology. Additionally, payment for full-time stable employment is usually effected through direct deposit to a bank account, thus making temporary work the mainstay for people experiencing homelessness, which typically ensures instability. As homelessness persists there appear to be a symbiotic relationship occurring between temporary employment agencies, cash corners ... and homelessness.

$40 \quad$ Zwarun, supra note 32.

$41 \quad$ Calgary Herald, supra note 31.

42 Ibid.

43 Ibid. A Hotel Arts manager cited that he is worried about illegal drug activity, vandalism and thefts.

44 See also "City growth forces labourers from home at Cash Corner," Canada.com (17 March 2008), online: <www.canada.com/calgaryherald/news/story.html?id=e5eb89ec-ecfc-4c7c-9fe3-efaddac321a6 $\& \mathrm{k}=42284>$ (parking meters are sprouting up and the street was earmarked for a volunteer walk of fame).

45 “City looks at regulating, moving 'Cash Corner,”' CBC News (7 February 2007), online: <www. cbc.ca/news/canada/calgary/story/2007/02/07/cash-corner.html>.

$46 \quad$ Ibid. As she stated, "We are condoning basically an illegal activity, where people are soliciting for work, and they're being paid in cash. And I doubt if they are paying tax on that money, so we shouldn't be in that business."

47 Ibid.

48 "New 'Cash Corner' location to be monitored," CBC News (6 March 2008), online: <www.cbc. ca/news/canada/calgary/story/2008/03/06/cash-corner.html> (because of new developments, "there's pressure on city council to make the spot a less desirable place to hang out”). 
users will be respected."49 A condominium developer agreed, citing that moving the Corner would create a safe environment at the current location. ${ }^{50}$ One Alderman however discounted moving Cash Corner, arguing the strategy should be to manage it through the design of the new site. ${ }^{51}$ Those occupying the new location however had concerns. A casino stated it is worried about the adverse affects Cash Corner would have on business and the safety of high school students who park nearby. ${ }^{52}$

On 17 March 2008, the City decided not to get involved. ${ }^{53}$ Citing concerns of liability, council voted down a plan to relocate the Corner. ${ }^{54}$ Despite the City's inaction, Cash Corner may be forced from its current location due to construction, forcing those frequenting Cash Corner to choose a new home for themselves. ${ }^{55}$ David Low, the executive director of the business revitalization zone states: "It's kind of like trying to squeeze Jell-O. It would only fragment and pop out elsewhere."

As of March 2011, condominium development had not started. ${ }^{57}$ As for the men on Cash Corner, it is business as usual with some gaining some notoriety in February 2011 when fifty Cash Corner men were hired by the City for snow removal at the National Hockey League Heritage Classic ${ }^{58}$ and also helping with the clean-up after a city-wide flood in July 2013. ${ }^{59}$

\section{Supra note 44.}

Ibid.

CBC News (6 March 2008), supra note 48 ("We're giving them the dignity of having public washrooms, some form of shelter. This specific area will be secure; it will be monitored").

Supra note 44. The casino stated: "There is no good reason to remind all the citizens of Calgary, commuting into downtown Calgary from the south, of Calgary's homeless problem. It is not fair to relocate Cash Corner to the EMS site in order to appease landowners owning lands near its present location to the detriment of landowners near the EMS site."

“City won't get involved in Cash Corner," Homeless Nation (17 March 2008), online: <www. homelessnation.org/node/8127>.

$54 \quad$ Ibid. Opposing the plan, Alderman Ric McIver stated: "When you have unlicensed workers, working for unlicensed contractors, who get hurt on the job, somebody's going to be looking to place the blame and get compensation and the city is a pretty big target.” See City of Calgary, Minutes of the Regular Meeting of Council (17 March 2008) at 47-48. Some feel the issue should be left to the market place (see e.g. Kohler, supra note 38).

55 Jeremy Klaszus, “Council says yes to cameras, no to moving Cash Corner,” fast forward weekly (20 March 2008), online: <www.ffwdweekly.com/news--views/news/council-says-yes-cameras-no-movingcash-corner/>.

$56 \quad$ Kohler, supra note 38.

57 “Cash Corner holding its ground,” Calgary Herald (27 March 2010), online: <www2.canada.com/ calgaryherald/news/story.html?id=799bd14e-73df-43a7-948b-b9f2835f9ae2>.

58 Bill Kaufmann, “Snow frustrates Heritage Classic organizers,” Calgary Sun (16 February 2011), online: <www.calgarysun.com/news/alberta/2011/02/16/17303001.html>.

Jeremy Nolais, “'There’s good money to be made’: Business plans formed around Calgary flood cleanup,” Metro Calgary, online: <metronews.ca/news/calgary/750887/theres-good-money-to-be-madebusiness-plans-formed-around-calgary-flood-cleanup/>. 


\section{Legal Tools Used to Control Persons at Cash Corner}

Having abandoned proposals to either move Cash Corner or provide facilities for Cash Corner, the City has not turned a blind eye. The City has been strictly enforcing the street bylaw, ${ }^{60}$ public behaviour bylaw, ${ }^{61}$ waste and recycling bylaw, ${ }^{62}$ and the panhandling bylaw. ${ }^{63}$ The bylaws share the purposes of promoting peace, order and good governance, and also the health, safety, morality, and welfare of the people and property. ${ }^{64}$ Some bylaws aim to "regulate problematic social behaviours that may have a negative impact on the enjoyment of public spaces" 65 and "ameliorate the negative impact” of particular activities. ${ }^{66}$ Engaging in prohibited activities leads to a variety of consequences including fines, and summary convictions with a fine or period of time in prison. ${ }^{67}$

\section{THE EFFECTS OF THE BYLAWS}

The City's use of bylaws is not a neutral act. Hoskins finds that in the course of regulation, public spaces "became terrains in which various legitimate and illegitimate constituencies were defined and constructed."68 Drawing from sociolegal research, we can see two main effects the enforcement of bylaws have on day labourers at Cash Corner. First, the bylaws have an exclusionary and unjust effect. Municipal rules and regulations are used to secure the public realm for the so-called respectable "through the exclusion of the unrespectable [such that] the city becomes increasingly hostile" to those who do not conform with the rules. ${ }^{69}$ Further, the proximity of informal economies to private property reveals that those

City of Calgary, by-law No 20M88, Street Bylaw (11 September 2011), ss 3-5. The Street Bylaw prohibits soliciting or selling on sidewalks without authorization by the city. Violating these provisions would lead to fines of $\$ 100$ to $\$ 200$.

61 City of Calgary, by-law No 54M2006, Public Behaviour Bylaw (20 November 2006), ss 4-6. Its stated purpose is to "regulate problematic social behaviours that may have a negative impact on the enjoyment of public spaces" and to promote the "safety, health and welfare of people and the protection of people and property.” The Public Behaviour Bylaw prohibits public urination, spitting, and loitering. Violations lead to a summary conviction with maximum penalties of $\$ 10,000$ fine or six months in prison. City of Calgary, by-law No 20M2001, Waste and Recycling Bylaw, s 4. The Waste and Recycling Bylaw, which is also aimed at promoting the safety, health, and welfare, of people, prohibits scavenging with a fine of $\$ 125$.

63 City of Calgary, bylaw No 3M99, Panhandling Bylaw, s 8. The Panhandling Bylaw is often used and cites panhandling as a "significant social safety concern" aimed at promoting "alternative income generating or support options" to "ameliorate the negative impact of panhandling activities.” Violating this bylaw leads to a summary conviction with a fine no greater than $\$ 10,000$ or time in prison. Morgan Modjeski, "City of Calgary panhandling tickets double since 2009,” Metro (19 February 2005), online: $<$ metronews.ca/news/calgary/1292665/city-of-calgary-panhandling-tickets-double-since-2009/>. Street Bylaw, supra note 60; Public Behaviour Bylaw, supra note 61; Waste and Recycling Bylaw, supra note 62; Panhandling Bylaw, ibid.

Public Behaviour Bylaw, supra note 61.

Panhandling Bylaw, supra note 63.

See supra notes 60-63; see also Jones, Shier \& Graham, supra note 32 at 138 where the authors write about how the lack of identification and a stable address causes conflict between homeless persons and police in public spaces: "A lack of ID and a stable address often means a trip to the police station rather than a mere warning or a ticket. Further, this may lead to other consequences with respect to employment or even obtaining a place at the homeless shelter."

68 Hoskins, supra note 5 at 9-10; see also Phil Hubbard, "Sex Zones: Intimacy, Citizenship and Public Space” (2001) 4:1 Sexualities 51 at 51; Kevin Hetherington, Expressions of Identity: Space, Performance, Politics (London: Sage, 1998); Linda McDowell, "City Life and Difference: Negotiating Diversity” in John Allen, Doreen Massey \& Michael Pryke, eds, Unsettling Cities (London: Routledge, 1999) 101; David Sibley, Geographies of Exclusion: Society and Difference in the West (London: Routledge, 1995) (according to Hubbard, ibid, many find that space "is not a passive backdrop to human behaviour and social action, but is constantly produced and remade within complex relations of culture, power and difference”).

69 Nicholas Fyfe, Jon Bannister \& Ade Kearns, “(In)civility and the City” (2006) 43:5/6 Urban Studies 853 at 854 . 
who have private property understand public space to be a finite public resource where the interests of property owners should be given more weight than those who do not own property nearby. ${ }^{70}$ The existence of informal economies are acceptable when we ourselves are using cleaners or babysitters, but is not acceptable when the community views the transaction on their streets.

Second, the current regulation of public space reflects darker, hidden agendas, such as fear and revulsion. ${ }^{71}$ Municipal regulations represent an overriding discourse about marginalized communities in public spaces: they are "nuisances (or worse) to be rid of — pests and vermin who sap the economic and social vitality of the cities and the nation."72 Similarly, persons who use the sidewalk for purposes other than walking or transportation are rendered intrusions or obstacles that fetter circulation or the sidewalk agenda. ${ }^{73}$ The city engages the law to perform social purification. ${ }^{74}$ The use of the law to exclude and control marginalized persons has acted to define citizenship. In this sense, citizenship refers to "the political and social recognition that is granted to those whose behaviour accords with the moral values underpinning the construction of the nation-state." ${ }^{\text {,75 }}$

The work of sociolegal scholars illuminates that the City of Calgary's approach to dealing with the existence of Cash Corner focuses on not only excluding day labourers from public space, but also generating a particular discourse surrounding day labourers that amounts to instilling fear and revulsion at persons congregating in public spaces.

\section{FINDING ORDER IN CASH CORNER}

\section{A. The Shortcomings of Legal Responses So FAR}

The work of sociolegal scholars intimate that the City of Calgary is using existing bylaws not only to regulate the behaviour of persons in public spaces, but also to exclude certain persons in order to create a specific ideal of order in public spaces. While the law may purport to be neutral, disinterested, and driven by rule determinacy and rights, legal scholars have pointed out that such a characterization of law applied to persons in public spaces is a myth. $^{76}$

See e.g. Hubbard, supra note 68 at 54 . Hubbard points out that persons who "transgress sexual and spatial order" have different rights when occupying public space and how "assumptions about the right of different groups to occupy space serve to reinforce hegemonic heterosexuality.” See also Glen S Elder, "The South African Body Politic: Space, Race and Heterosexuality” in Heidi J Nast \& Steve Pile, eds, Places Through the Body (London: Routledge, 1998) 114.

71 Don Mitchell, The Right to the City: Social Justice and the Fight for Public Space (New York: Guilford, 2003) at 196-97.

Ibid at 197.

Blomley, supra note 26 at 20 (using the law, cities have constructed the sidewalk not as a political space or a civic arena, but simply a site for walking).

Ibid at 16.

Hubbard, supra note 68 at 53.

See e.g. Austin Sarat, ““...The Law is All Over’: Power, Resistance and the Legal Consciousness of the Welfare Poor” (1990) 2:2 Yale JL \& Human 343 (marginalized persons see the law as no different from politics at 356). Sarat conducted ethnographic research on how welfare recipients experience the law. He writes at 359: "The law as the welfare poor experience and understand it is grounded in the realities of a society in which race, wealth, and power matter, and law is neither more or less useful because it does not transcend or transform the world as they know it." 
Armed with these revelations, the approach adopted thus far is one that does not lead to order. The way that the City is dealing with Cash Corner is ineffective in two ways: it has not reduced conflict in public space and it has not eliminated the existence of Cash Corner. Persons at Cash Corner are frequently and constantly in conflict with bylaws, and with those that live and work in the neighbourhood. Some scholars have explored why legal responses have not led to the order a city expects. ${ }^{77}$ There are two reasons why current legal approaches have been ineffective.

First, while the legal tools employed by municipalities aim simply to rid certain persons from public spaces, the laws do not recognize the subsistence uses to which cities are put; the laws do not eliminate the factors that bring marginalized communities to public spaces. Duneier writes: "Surely, the people working and/or living on the sidewalk cannot be done away with so easily, even if it were desirable. Those determined to make 'an honest living' will keep deploying their creativity, competence, and cultural knowledge ... to survive."78 Similarly, Sarat finds that marginalized persons are not "passive recipients" of the law and that they respond strategically to manoeuvre and resist the law. ${ }^{79}$ Thus, despite the enforcement of laws aimed at curbing certain kinds of behaviour or eliminating particular persons from public spaces, we find marginalized communities still congregating in public spaces. We find that Cash Corner continues to exist fifty years on because the legal responses thus far do not recognize the factors that bring people to the Corner, and also the order that they live in.

Second, legal responses thus far are premised on the notion that we desire and live amongst a homogenous and equal society. Some scholars have pointed out that the problem with current legal responses is the lack of recognition that marginalized communities in public spaces experience the law in a starkly different way than those of us that can retreat to private spaces. ${ }^{80}$ As Jeremy Waldron discusses: "What is emerging — and it is not just a matter of fantasy — is a state of affairs in which a million or more citizens have no place to perform elementary human activities like urinating, washing, sleeping, cooking, eating, and standing around." ${ }^{81}$ Further, marginalized persons are caught inside the law despite being excluded from the "construction of the meaning" or the "interpretive community of the law" which they regularly encounter. ${ }^{82}$ As Hirst finds, policing marginalized communities amounts to enforcing "hierarchical control in complex circumstances that render it ineffective."83

Not only is the legal regime ineffective, but it also creates false expectations and a false notion of order. In crafting unrealistic ideas about what constitutes order in public spaces, the law fosters more discordance amongst community members.

See e.g. Paul Hirst, “Statism, Pluralism and Social Control” (2000) 40 Brit J Criminol 279 at 280. Hirst questions whether "social control through the legal order and institutionalized policing is now effective". Mitchell Duneier, Sidewalk (New York: Farrar, Straus and Giroux, 1999) at 313.

Sarat, supra note 76 at 346.

See e.g. Jeremy Waldron, "Homelessness and the Issue of Freedom” (1991) 39:1 UCLA L Rev 295 at 300 [Waldron, "Freedom"]. "For the most part the homeless are excluded from all of the places governed by private property rules, whereas the rest of us are, in the same sense, excluded from all but one (or maybe all but a few) of those places” [emphasis in original].

Ibid at 301.

Sarat, supra note 76 at 345-46; see also Robert Cover, "Violence and the Word" in Martha Minow, Michael Ryan \& Austin Sarat, eds, Narrative, Violence, and the Law: The Essays of Robert Cover (Ann Arbor, University of Michigan Press: 1993) 203; Waldron, "Freedom,” supra note 80 at 299. Hirst, supra note 77 at 281. 
Given that the strategies employed have not been useful in cleansing marginalized persons from public space or bringing the particular order the city envisions, we should take up Hirst's challenge of looking at more "diverse, decentralized, and self-regulatory strategies." 44 As it stands, the community should look for a different way to interact with one another. Recognizing that the current state of the law does more harm than good, how can courts, as arbiters of the use of public space, bring more harmony to the sidewalks and streets? As Waldron posits:

In the end it comes down to a connection between community and authenticity.... So long as people live among us in a condition of homelessness, our normative definitions of community must be responsive to their predicament; and it must be responsive, not only in articulating some vague sense of social obligation to 'do something' about the problem, but in accepting that the very definition of community must accommodate the stake that the homeless have — as community members — in the regulation of public places. ${ }^{85}$

I argue that we ought to turn to the revelations of ethnographers that have mapped out different kinds of norms in public space; that we recognize that there are different kinds of order that can exist in a community. I argue that we should extend the work of sociolegal scholars by talking about remedies that include the recognition of different kinds of normative orders.

\section{B. Using a Legal Pluralism Framework to View Cash Corner}

\section{What IS LEGAL PLURALISM?}

Legal pluralism is generally understood as a situation in which two or more normative orders coexist in the same social field. ${ }^{86}$ Non-legal forms of normative ordering are included and exist in a variety of places. ${ }^{87}$ Sally Engle Merry finds "normative orders are informal systems in which the processes of establishing rules, securing compliance to these rules, and punishing rulebreakers seem natural and taken for granted." ${ }^{88}$ While most work in legal pluralism began in examining relationships between colonized and colonizer, legal pluralism now also looks at relationships between dominant and subordinate groups of people in advanced industrial countries. ${ }^{89}$ This kind of analysis looks at not only the effect of law on society or even society on law, but also at official and unofficial forms of ordering and their relationships with one another. ${ }^{90}$

While there are different understandings of what legal pluralism means, there are some common elements that legal scholars agree upon. First, legal pluralism scholars agree that

Ibid.

Jeremy Waldron, "Homelessness and Community" (2000) 50:4 UTLJ 371 at 406 [Waldron, "Community"].

Sally Engle Merry, “Legal Pluralism” (1988) 22:5 Law \& Soc’y Rev 869 at 870 [Merry, “Legal Pluralism”]; see also Franz von Benda-Beckmann, Keebet von Benda-Beckmann \& Anne Griffiths, eds, Spatializing Law: An Anthropological Geography of Law in Society (Surrey, UK: Ashgate, 2009) at 4 (scholars argue that studying the law of space requires a legal pluralism lens "for it highlights the ways in which legal constructions of space ... operate with their own spatial claims for validity”). E.g. within families, corporations, and communities: Merry, "Legal Pluralism,” ibid. Ibid at $870-71$.

Ibid at 872 .

Ibid at 873 . 
the concept of legal pluralism describes "multiple systems of ordering in complex societies."11 Sally Falk Moore defines these multiple systems of ordering as being able to "generate rules and customs and symbols internally, but that...is also vulnerable to rules and decisions and other forces emanating from the larger world by which it is surrounded." 92

Second, legal pluralists reject the notion of "legal centralism" or a focus on state law. ${ }^{93}$ The concern is that law-centred traditional study of law ignores legal phenomenon taking place outside of state institutions. The focus is to study other forms of social regulation that "draw on the symbols of law, to a greater or lesser extent, but that operate in its shadows." "94 As Chris Fuller writes: “'law-centered' perspective fatally impedes the proper study of social order and dispute" and that "state law, contrary to its own ideology, never enjoys unambiguous and unchallenged dominance." 95

Third, legal pluralism provides a frame upon which one can critically analyze law's preoccupation with state law. ${ }^{96}$ The concept of legal pluralism does this by showing that different norms and rules may exist in a particular space and these mechanisms for social control are also a "species of social imagination" that allows people to decide how they are going to live. ${ }^{97}$ The main preoccupation with legal pluralism is bringing in the sociological and anthropological concept that social realities may be very different than the order imagined by the law. Legal pluralism is the "study of law as a system of meanings, a cultural code for interpreting the world."98

Finally, most legal pluralists understand that there is some interaction between the different normative orders. Some study the interactions or influences these orders have on one another. ${ }^{99}$ Others recognize that "certain norms or clusters of norms dominate particular spatialized practices”100 and there does not need to be convergence between multiple

Ibid at 878; Sally Falk Moore, "Law and Social Change: The Semi-Autonomous Social Field as an Appropriate Subject of Study” (1972) 7:1 Law \& Soc'y Rev 719 at 720.

Merry, "Legal Pluralism," ibid at 878 (the semi-autonomous social field has rule-making capabilities, and the means to induce or coerce compliance; but it is simultaneously set in a larger social matrix which can, and does, affect and invade it, sometimes at the invitation of persons inside it, sometimes at its own instance); Moore, ibid at 720.

93 Merry, “Legal Pluralism,” ibid at 874.

$94 \quad$ Ibid

95 Chris Fuller, "Legal anthropology, legal pluralism and legal thought” (1994) 10:3 Anthropology Today 9 at 9,10 .

96 Ibid (this theory criticizes the claim of the "law of the state as the only normative order" at 10).

97 Ibid at 11; see also Merry, "Legal Pluralism," supra note 86 at 886, 889-90. Merry finds there are five ways of viewing sociolegal phenomena as plural. First, as a move away from legal centralism highlighting "competing, contesting, and sometimes contradictory orders outside state law." Second, it "requires a shift away from an essentialist definition of law" recognizing that other normative orders can exist and persist. Third, it "leads to an examination of the cultural or ideological nature of law and systems of normative ordering" allowing for the focus to shift from how particular rules are applied in situations to looking at ways that social groups conceive of ordering, social relationships, and determining truth and justice. Fourth, legal pluralism "facilitates the move away from an exclusive focus on situations of dispute to an analysis of ordering in nondispute situations.” And finally, "understanding the dynamics of the imposition of law and of resistance to law, for examining the interactive relationship between dominant and subordinate groups or classes." Merry, "Legal Pluralism," ibid at 886. Inquiry 203 "legal pluralism is helpful to understanding contact across divergent normative orders" at 209); see also Roderick Macdonald, "Metaphors of Multiplicity: Civil Society, Regimes and Legal Pluralism” (1998) 15:1 Arizona J Intl \& Comp L 69 at 77. 
norms. ${ }^{101}$ The plurality of norms can coexist and the interaction between these plurality of norms may affect social hierarchy, community passivity, or civil inattention to marginalized persons in public spaces. ${ }^{102}$

Thus, the theory of legal pluralism provides a contextualized lens upon which to view our social landscape by acknowledging that there may be multiple normative orders existing in a particular space, rejecting law's focus on state law, providing a framework upon which to critically look at state law and providing a vehicle to describe multiple orders and how they may interact with one another. Two main criticisms however, have been brought forward by legal scholars and are pertinent here. Both will be discussed below.

\section{The SEMANTIC CRITICISM OF THE DEFINITION OF LEGAL PluRALISM}

Some legal scholars argue that legal pluralism as a theory is faulty or unstable because legal pluralist scholars themselves do not have a consensus on the meaning of legal pluralism, leading to a view that "all forms of social control are law."103 Indeed Merry acknowledges that it is difficult to describe what non-state law is. ${ }^{104}$ The criticisms include that analytically, legal pluralism simply reminds us that "isolated, homogeneous societies do not actually exist" and that the concept merely serves to reproduce "law-centered miscontructions." ${ }^{105}$ As Merry herself describes, sometimes non-state orders appropriate or borrow symbols and mechanisms from state law. ${ }^{106}$

Critics however are fixated on semantics. Whether the orders are legal or not is simply an exercise in labeling. Despite the lack of a clear consensus, for the purpose of this article, guidance is taken from Merry who uses the nomenclature of "normative orders" to avoid imputing state law characteristics on non-state law, and also to signal that some norms and rules may not be considered law under some definitions. ${ }^{107}$ What is important for our discussion is not whether non-state order really are reconfigurations of state law, but the recognition that there could be normative orders in public spaces that are different from state law and are not seen as an order by the community.

\section{The PREFERENCE FOR LEGAL MONISM}

Some legal scholars argue that for order to exist, there must be one overriding or centralized system that is deferred to. They argue that if there is no sole legal order that

Ibid.

Ibid at 228. See also Macdonald, supra note 100. Going further than just describing whether there is an interaction of various normative orders, legal pluralists such as Macdonald also provide a critical analysis of the interaction between the normative orders. For example, Macdonald at 79 writes that "nonconforming behaviour in any particular regime is not simply a failure of enforcement or civil disobedience. It may be the reflexion of an alternative conception of legal normativity.”

See e.g. Brian Z Tamanaha, “The Folly of the 'Social Scientific' Concept of Legal Pluralism” (1993) 20:2 JL \& Soc’y 192 at 192-93.

Merry, “Legal Pluralism,” supra note 86 at 878.

Fuller, supra note 95 at 10.

Merry, "Legal Pluralism,” supra note 86 at 882.

Ibid at 891. 
ultimately makes the final decision, then we risk chaos, uncertainty, and even violence in many forms. ${ }^{108}$

Legal pluralism scholars however, have found that from a descriptive perspective, legal monism simply does not exist. ${ }^{109}$ There is no one sole and overriding legal system practiced in many jurisdictions in the world. ${ }^{110}$ As Torres writes: "An examination of the Law-Space relationship that only emphasizes the formal legal system runs the risk of ignoring the diversity of regimes and systems that exist, as well as limiting the extent to which one can comprehend the complex social relationships that constitute space and its reality."111 Beyond the descriptive role of legal pluralism, scholars have also pointed out that a diversity of orders is plausible from a regulatory point of view, and would even "be a mechanism that would, among other things, contribute to the peace and cohesion of the political community." "112 Indeed, "[l]aw and legal institutions mean different things to different people."113

Similarly, some legal scholars have a preference for state law as the overriding or deferential choice to order. They argue that moving marginalized persons into the formal or state legal structures will lift them from their marginalized places into a more prosperous life. ${ }^{114}$ For example, Hernando de Soto advocates moving marginalized persons from informal spheres into formal institutions created or regulated by the state. ${ }^{115}$ Despite these calls for more state intervention, other scholars call these prescriptions presumptuous and problematic. Carmen Gonzales, for example, writes that benefits associated with greater state regulation are exaggerated and fail to consider risks involved. The push to formal or state legal orders assume that informal orders are undesirable and that such approaches neglect to

Daniel Bonilla Maldonado, “Extralegal Property, Legal Monism, and Pluralism” (2009) 40:2 U Miami Inter-Am L Rev 213 at 213 (violence in many forms includes a lack of protection of people's rights, equality, security, unity, and fairness in knowing what the rules are and the consequences to violating those rules).

Érika Fontánez Torres, "Law, Extralegality, and Space: Legal Pluralism and Landscape from Colombia to Puerto Rico" (2009) 40:2 U Miami Inter-Am L Rev 285 at 286. Torres suggests legal monism is flawed ... because they concede that the State is the only body capable of creating and promoting norms. Likewise, excessively legalistic worldviews are restrictive in the sense that they presuppose that legal discourse can flow only through the spaces of formal legal institutions. Such a legalistic worldview necessarily excludes any extralegal action, the creation of informal orders and norms and communicative actions that do not flow through formal institutional spaces.

110 See e.g. Maldonado, supra note 108 at 214 . Maldonaldo discusses how there is a diversity of property regimes that exist in a high number of developing countries. He writes that "approximately $50 \%$ of the population in the global South lives in peripheral districts where property is controlled by norms other than those of the State's legal order."

111 Torres, supra note 109 at 289. Torres points out how one community in Jerusalén in Bogotá has a normative system created by the community, that community members concepts of property and owner are different from formal definitions, and that both formal and informal systems interact through the incorporation of language and concepts.

112 Maldonado, supra note 108 at 215. He also writes that "the existence of 'informal' or 'unofficial' regimes that regulate property, insofar as they are created directly by the citizens, would allow for the adjustment of legal norms to the characteristic particularities of each social group and for the quick and easy alteration of them in accordance to changes that the groups experience." Merry, "Legal Pluralism," supra note 86 at 885.

See e.g. World Bank, Housing: Enabling Markets to Work (Washington, DC: World Bank, 1993) at 117, online: <documents.worldbank.org/curated/en/1993/04/1561159/housing-enabling-markets-work>. 
address the underlying causes of poverty, inequality, and informality. ${ }^{116}$ Increased regularization is "dangerous to the extent that they lull law-makers into believing that the 'free market' will resolve the problem."117 As well, Sheila Foster argues that perhaps boosting a community's "capacity for self-governance" and using the "collective efforts of a community" can help with the management of "collective or common urban resources."118 Foster provides ideas in leveraging public-private partnerships in which the government provides initial support and investment in the neighbourhood and then allows communities to take charge and continue the work on their own in partnership with government. ${ }^{119}$

\section{What Legal Pluralism CAN Bring to The TABle}

As discussed, the existing legal regime regulating Cash Corner has been ineffective in reducing conflict, and ridding Cash Corner. The focus on state law and on choosing between competing interests has not brought durable harmony, and has fostered a false notion of order.

With a legal pluralism lens, courts can focus less on the relationship parties have with state law and recognize that non-state orders can provide ideas for remedies to ongoing conflicts. While legal pluralists focus on how "law is intimately involved in the constitution of social relations," ${ }^{120}$ this article is more interested in how courts are creators of cultural meanings and how these institutions can reshape popular legal consciousness surrounding marginalized communities in public spaces. ${ }^{121}$ Instead of using discourse about competing rights, when discussing remedies, the discussion can look at whether different orders may coexist. The lens of legal pluralism can posit different ideas of what public space can be used for, and accommodate different lifestyles amongst community members. ${ }^{122}$ This is a different approach than current legal responses. Existing approaches simply focus on naming and labelling persons and behaviour in public spaces. ${ }^{123}$ To conceptualize how different remedies can be concocted, the next section points to ethnographic research to show that order can exist in public spaces amongst marginalized communities.

\section{THE ORDER THAT EXISTS}

Many legal pluralists have identified the existence of informal systems in different public spaces. They have found that gaps presented by existing law can lead to the appropriation of regulation or norm-creation to members in a local community. For example, Jane Jacobs wrote:

Carmen G Gonzales, "Squatters, Pirates, and Entrepreneurs: Is Informality the Solution to the Urban Housing Crisis?” (2009) 40:2 U Miami Inter-Am L Rev at 239; see also Alan Gilbert, “On the Mystery of Capital and the Myths of Hernando de Soto" (2002) 24:1 Int'l Dev Plan Rev at 1, 4. Gonzales, ibid at 257.

Foster, supra note 39 at 284.

Ibid at 283.

Sally Engle Merry, “Culture, Power and the Discourse of Law” (1992) 37:1\&2 NYL Sch L Rev 209 at 209 [emphasis in original].

Ibid at 211.

Ibid at 220

Ibid at 223. 
The first thing to understand is that the public peace — the sidewalk and street peace — of cities is not kept primarily by the police, necessary as police are. It is kept primarily by an intricate, almost unconscious, network of voluntary controls and standards among the people themselves, and enforced by the people themselves.... No amount of police can enforce civilization where the normal, casual enforcement of it has broken down. ${ }^{124}$

We can use the lens of legal pluralism to help us map rules and customs that exist in Cash Corner. While empirical work needs to be done to discern the exact nature of the order on Cash Corner, we can turn to ethnographic research on informal economies in other public spaces to give us a sense of what may exist on Cash Corner. I turn to three studies to help with this task.

\section{BOOK AND MAgAZINE SELLERS IN NEW YORK CITY}

Mitchell Duneier's ethnographic study of book and magazine sellers in Greenwich Village in New York provides a salient example of how informal order can be found in public spaces. ${ }^{125}$ Duneier looks into the factors and reasons that led the persons not only to live, but work on the street. In doing so, he illuminates the informal rules that govern who will survive, and indeed succeed on the street. For example, Duneier identifies different roles that people play on the street to sustain themselves and also the informal institution of book and magazine selling on the street: the "place holders,"126 "table watchers,"127 "movers,"128 and the "storage providers." 129 Duneier also discusses the rules on the street namely, who can take up space, ${ }^{130}$ how to bargain with customers, ${ }^{131}$ how to build a customer base, ${ }^{132}$ what books and magazines are in demand, ${ }^{133}$ and how to hunt for used goods. ${ }^{134}$ With regards to obtaining used goods, Duneier writes that "The magazine scavengers of Sixth Avenue tend

Jane Jacobs, The Death and Life of Great American Cities (New York, Random House, 1961) at 31-32. See also Foster, supra note 39 ("It is astonishing how, in the absence of a formal planning function or capacity, many [informal] settlements come to resemble other, formally planned 'legal' neighborhoods with stable property regimes" at 281); Julia Eckert, "Urban Governance and Emergent Forms of Legal Pluralism in Mumbai” (2004) 36:50 J Legal Pluralism \& Unofficial Law 29 (the use of informal courts are due to the "inefficiency and inaccessibility of the state courts").

Duneier, supra note 78.

They hold the scarce vending space for the vendors when they cannot be on the street to keep their place, mostly at night when the vendors are away. Duneier writes: "An informal system governs property rights on the street" (ibid at 85).

They are paid by vendors to stand behind second and third tables of goods that they cannot watch over, and often relieve the vendors when they need to use a washroom, eat, or hunt for more used goods to sell (ibid at 88).

They move goods stored in places off the street at night to the street during the day (ibid at 92). Those who find space for vendors to store their goods at night and are paid "rent" for holding these goods (ibid at 94).

Ibid at 85 .

Ibid at 67.

Ibid at 70 .

Ibid at 73 .

Ibid at 149 . 
to take great pride in leaving the trash they sort through neat and orderly."135 They abide by these rules to ensure that the City does not intervene in their "livelihood" and to prevent the community from complaining about their activities. ${ }^{136}$ Duneier also reveals social support and mentoring is exchanged between older venders and younger vendors. ${ }^{137}$

\section{BINNERS IN CALGARY}

Cori Bender provides a local ethnographic study of persons who "bin” or scavenge "through garbage bins with the prospect of finding reusable and recyclable items that can be exchanged for cash." ${ }^{138}$ Bender finds that binners are hard-working. ${ }^{139}$ They begin their day between 5:00 and 7:00 a.m. covering 25 kilometres of foot travel, earning between $\$ 25$ and $\$ 40$ a day. ${ }^{140}$ Similar to Duneier, Bender finds that there exists a “mentor/novice relationship between new informal recyclers and established ones.”141 As well, binners maintain work ethic through established norms:

A majority noted they attempt to maintain a high level of cleanliness along their routes. To the point of picking up after those few binners who do not respect the work ethic and leave garbage on the ground surrounding the bins. They feel it is important to establish positive public relations, and one way to do so is by maintaining cleanliness along routes. ${ }^{142}$

\section{IMMIGRANT DAY LABOURERS IN BROOKLYN}

Carolyn Turnovsky's ethnographic study of immigrant day labourers in Brooklyn provides an analogous case study to Cash Corner. ${ }^{143}$ She looks at a public space called la parada:

Ibid at 150; see also Karabanow et al, supra note 34 at 56 wherein the authors state that

[e]ngaging in work — even informal work — can provide these otherwise excluded youth with a sense of accomplishment and, depending on the activity, meaningful work. Engaging with the public and sharing particular life stories can be a way for street youth to reflect on their experiences, and in some cases, feel pride in how they have managed to survive and get by with much less than most.

The authors continue that youth often reflect on their work as providing a service or entertainment. See also Karabanow et al, ibid at 51: "Within these collectives, there appears to be a strong street etiquette concerning work arrangements. Contrary to the common perception of the streets having 'no rules,' there was indeed a clear structure/honor code to engaging in informal work, consisting of, first and foremost, respect."

136 Indeed, some community members go so far as to facilitate these people with their search by making accommodations for them, separating goods from trash (Duneier, ibid).

137 Duneier describes a relationship between book vendor Hakim and a young black individual who works in a vitamin store named Jerome: ibid at 36, 74 . Duneier also provides a profile on the relationship between two men who work on the street, Marvin giving social support and mentoring to Ron). See also Karabanow et al, supra note 34 at 51 ("[Y $]$ outh create their own community (or 'family') on the street in response to the shared difficulty and hardship they face”). Cori Bender, Informal Employment: Making a living in Calgary, Final Report (Calgary Homeless Foundation, 2010) at 2, online: Calgary Homeless Foundation <calgaryhomeless.com/wp-content/ uploads/PanhandlingReportSubmittedToCHFSept212010.pdf>. See also Karabanow et al, supra note 34 at 48 ("The daily routine of homelessness and informal work is not significantly different from the routine required to maintain formal work.") Bender, supra note 138 at 5.

141 Ibid at 6. Bender writes: “In response to the question 'how did you come to learn about binning?' many respond that it was first through observing someone doing it, and then that individual showing the novice how to bin effectively. Many long term informal recyclers give freely of their expertise, although there seems to be a particular dynamic involved with who chooses to help others, and why." Ibid at iii.

Carolyn Pinedo Turnovsky, Doing the Corner: A Study of Immigrant Day Laborers in Brooklyn, New York (D Phil Dissertation, The City University of New York, Graduate Faculty in Sociology: UMI, 2006). 
La parada was their office, but it was also the tavern or club where they drank and chatted with friends. More than a geographical space in the urban landscape that was reconstructed as a hiring site or as a makeshift club to pass the time, la parada provided the men with a space where they discovered camaraderie and renewed a sense of community and membership. ${ }^{144}$

Turnovsky discovered that many preferred la parada to the formal centre created to help match men and work. ${ }^{145}$ There are several reasons for this: the social attachment to the networks and connections made at la parada; ${ }^{146}$ "the loss of control over the conditions of their work situation, particularly the rules at the center that would regulate their actions in the hiring process"; ${ }^{47}$ and the difference in rules about wages, law enforcement, and community membership. ${ }^{148}$

Turnovsky highlights some of the norms that exist at la parada. First, she discovered that the men at la parada "agreed on a minimum wage rate among themselves and this varied little from group to group.”149 This ensured a guaranteed rate and prevented men from bargaining down the pay scale just to get work, thus not weakening the ability of the men to make decent pay for a day's work. ${ }^{150}$ Second, the men "placed significant value in the right to accept, but also decline work opportunities, especially from men who had the reputation of being dishonest, i.e. withholding or denying payment."151 This ensured that, as a group, they would garner respectful treatment. The men also wanted a choice of work, depending on the difficulty of the work, the skills they possess, and the time they had. ${ }^{152}$ Third, Turnovsky found, as did Duneier and Bender, that the men provided support and mentorship for one another. The men would suggest their friends to accompany them on the job to help complete tasks and how they would use those as learning opportunities as well. ${ }^{153}$

\section{IDENTIFYING ORDER THROUGH IDENTIFYING THE NORMS}

We can see from ethnographic studies conducted by Duneier, Bender and Turnovsky a sample of various orders present in public spaces. Each provides an account of the norms that exist to ensure the existence of the informal institutions that marginalized persons use to live and survive while recognizing that the persons using such informal economies do so for reasons of personal dignity and responsibility. ${ }^{154}$

In reviewing the various types of rules that make up these spaces, I borrow Frederick Schaeur's taxonomy of reasons for rules to illustrate how discovered norms in informal

\section{Ibid at 122.}

Ibid at $123-24$.

Ibid at 123 .

Ibid.

Ibid at $123-24$.

Ibid at 125 .

Ibid.

Ibid at 127

Ibid.

Ibid at 135 .

Shier, Jones \& Graham, supra note 29 at 459-61 ("some respondents want to avoid imposing on their family or friends.... Underlying many of the statements in this category are issues of personal dignity and personal responsibility.") They also write that some respondents accessed support from family and friends but nothing that would place them in a dependent relationship and that many did not access support because they were embarrassed about being homeless. 
economies in public spaces give order. ${ }^{155}$ Schaeur helps us understand the norms that shape the informal institutions in public spaces serve different useful purposes for persons working in the streets.

The ethnographic works canvassed demonstrated four categories of rules. The first deals with pay. Marginalized persons have agreed amongst themselves the appropriate pay for the work they do and hold to that when they are negotiating with potential employers or customers. ${ }^{156}$ Schaeur views these norms as promoting fairness, reliance, predictability, and certainty. $^{157}$

Second, ethnographic research reveals that marginalized persons working in public places have a reporting mechanism by which to notify others of employers or customers who are dishonest in the way that work or pay is given, or if they do not provide safe working environments. ${ }^{158}$ Schauer views these rules as fostering reliance, predictability, and certainty. ${ }^{159}$

Third, persons working in informal economies in public understand that their livelihood depends on their ability to exist in public places undisturbed. The general understanding is that to keep law enforcement at bay, they need to keep the corner, or their workspace up to certain standards. ${ }^{160}$ Again, Schauer views these rules as ensuring reliance, efficiency, and stability. ${ }^{161}$

Finally, marginalized persons in public spaces have rules to ensure employers or customers will continue to use their services or buy their goods. They ensure this by recommending persons as options for day labour according to qualifications, by using or proposing additional individuals to accompany them to complete jobs, and instituted de facto mentoring processes. ${ }^{162}$ These mentoring processes allow persons to learn from more experienced members aspects of surviving on the corner such as how to negotiate with employers and customers, how to conduct themselves, and other relevant skills. ${ }^{163}$ Sometimes relationships persons have with one another on the street also extend beyond mentoring to providing basic needs, such as sharing extra food, ${ }^{164}$ unwritten norms about theft of personal

Frederick Schauer, Playing by the Rules: A Philosophical Examination of Rule-Based Decision-Making in Law and in Life (Oxford: Clarendon Press, 1991).

See e.g. Turnovsky, supra note 143 at 125; see also Karabanow et al, supra note 34 at 49 wherein the participants in a study stated that informal work provided opportunities for expressions of autonomy (such as creativity, entrepreneurship) that buffer the controlling forces associated with other activities of daily life.

Schauer, supra note 155 at $135-58$

See e.g. Turnovsky, supra note 143 at 127.

Schauer, supra note 155 at 135-58.

See e.g. Duneier, supra note 78 at 158; Bender, supra note 138 at iii; see also Karabanow et al, supra note 34 at 51-52 (youth street workers had strong etiquette concerning work arrangements and, contrary to the common perception of the streets having 'no rules,' there was a clear structure or honour code to engaging in informal work, consisting of, first and foremost, respect). Schauer, supra note 155 at $135-58$.

See e.g. Duneier, supra note 78 at 36; Bender, supra note 138 at 6; Turnovsky, supra note 143 at 135. Ibid.

Persaud, McIntyre \& Milaney, supra note 29 at 346: "the men reported that if they knew someone was hungry and they had extra food, they would share. As James explained, "When I can give, I will, and when I can't ... it's because I really can’t, it’s because I need to survive, too, right?” 
property, ${ }^{165}$ safety, and social integration. ${ }^{166}$ Schauer would view these norms as providing coordination and cooperation. ${ }^{167}$

In pulling these common strands from ethnographic work, we can see that some sort of order can and does exist in public spaces amongst marginalized communities. In making this observation, I understand that some normative value may be given to the order that exists on Cash Corner and that there may be other circumstances in which we may not want to give such recognition to a set of rules. For example, some scholars are reluctant to give normative value to religious laws in secular, democratic settings. ${ }^{168}$ In those circumstances, we can take guidance from the work of legal pluralists who have developed evaluations to help us decide whether to recognize a particular order. For example, the International Council on Human Rights Policy has crafted a framework with six dimensions by which an order can be assessed. ${ }^{169}$ The ultimate question to be answered by assessing rules through this evaluation is whether such an order will advance a program of justice or adheres to particular human rights standards. ${ }^{170}$ Such an evaluation can be crafted and applied to orders found in public spaces. This, however, is beyond the scope of this article.

\section{How Legal Pluralism Changes Discourse Around Cash Corner}

Recognizing some normative order exists in public spaces outside of state law is just the beginning. The work of ethnographers should be extended and their research mined for ideas when crafting remedies for conflicts that arise in public spaces amongst various community members. Using a legal pluralism can aid in reaching durable remedies in three main ways.

\section{REDEFINING ORDER}

First, by pointing out diverse or multiple normative orders in a particular space, legal pluralism can challenge the notion of what it means to have order in public space. As Julia Eckert finds, the emergence of another order in a particular space can be told in "two apparently contradictory ways" as either a story of the "failure of governance" by the state or as the growth of "local modes of governance." "Showing that different orders are present can focus courts on the idea that there are emerging local modes of governance rather than

Ibid at 347: "Closely modeling the proverbial Golden Rule, men were very clear about the unacceptability of taking advantage of others. For instance, although theft of personal property was prevalent, it remained highly stigmatized."

Ibid at 347: "although men frequently shared resources, friendships predominantly provided companionship, safety, and social integration: 'a friendship is pretty much as golden down here as money. To have friends down here, um, pretty much guarantees your safety, um, pretty much guarantees that you don’t go crazy from being lonely’ (Bill).” Persaud, McIntyre, and Milaney also discuss the concept of the "zone" where people went to specific shelters based on their social networks); see also Karabanow et al, supra note 34 at 50-51 where the study found that young people on the street create their own community structures (family, tribes, or crews) which are group-centred and focused on needs. One participant stated, “we're very communal people, very contributing to each other, very aware of each other's needs” and that working and living in groups was about feeling safer, especially for women. Schauer, supra note 155 at 162-67.

See e.g. Bryan S Turner, “Legal Pluralism, State Sovereignty, and Citizenship” (2011) 7:4 Democracy and Security 317.

International Council on Human Rights Policy (ICHRP), When Legal Worlds Overlap: Human Rights, State and Non-State Law (Versoix, Switzerland: International Council on Human Rights Policy, 2009) at $115-57$.

Ibid.

Eckert, supra note 124 at 56. 
a failure of the state to control public space. We can shift the discourse from that of a failure of the state to maintain order to asking how order can be reimagined to include all community members. The discussion can be more inclusive of different perspectives of what order means to different people. Instead of discussing conflicts as a question of whether appropriate "social controls"172 are being used, how to resolve "chronic street nuisances,"173 how society can "discipline miscreants," ${ }^{174}$ or how to "manage” public spaces, ${ }^{175}$ we can mediate between different interests amongst all citizens. Indeed, those using the street for informal economies “are very aware of how they are positioned 'in society.' Some view themselves living outside of society, but others argue that they must be part of society because their work is consistently situated within the public realm." "176

Some legal scholars argue, "maintaining the invitingness of streets, sidewalks, and parks is essential to the viability of an urban neighborhood." 177 This perspective however resembles a preconceived and particular notion of what "viability" or "order" means and what is an inviting neighbourhood. It imposes a particular notion of order and ignores the possibility of the plurality of orders in one space. It also ignores the interests of community members that may not share that same notion of order. Typically it means that interests of the "majority" dictate what is "good order." ${ }^{178}$ As Ellickson writes: "to be truly public, a space must be orderly enough to invite the entry of a large majority of those who come to it." "These views however, are based on fears and stereotypes. Indeed as Ellickson states: "the activity of begging, unlike many other forms of street nuisance behavior, is likely to signal erosion of work ethic.”180 Ethnographic research of reveal however, that there is no lack of work ethic amongst marginalized persons in civic spaces. ${ }^{181}$ As well, those working in public space often "describe the futility of criminalizing informal work as a means to address homelessness and poverty." 182

Recognizing different orders in particular spaces is not enough. In shedding light on the norms that may drive the perpetual existence of marginalized communities in public spaces, courts should explore different approaches. One is to lessen the focus on the strict enforcement of bylaws since order envisioned by bylaws should not be prized as an end in

Ellickson, supra note 25 at 1168.

Ibid at 1169.

Ibid at 1172 .

Ibid. Ellickson concedes, "there is universal agreement that every person, no matter how scorned, is entitled, assuming he behaves himself, to walk on every public sidewalk and to sit on every bench in every public park. The examples of protracted panhandling and bench squatting fall in the baffling normative terrain that lies between these easier cases.”

Karabanow et al, supra note 34 at 55.

Ellickson, supra note 25 at 1171; see also James Q Wilson \& George L Kelling, "Broken Windows: The Police and Neighborhood Safety” Atlantic Monthly (March 1982) at 29, 31-32; William J Bratton, "The New York City Police Department’s Civil Enforcement of Quality-of-Life Crimes” (1995) 3:2 JL \& Pol'y 447 at 448-50: Wilson and Kelling were behind the broken windows theory whereby they theorized persistent minor disorders not only disturbs a neighbourhood but if not dealt with, would encourage more disorder and may lead to more serious criminal acts.

Ellickson, ibid at 1174.

Ibid.

Ibid at 1182.

See e.g. Duneier, supra note 78; Bender, supra note 138; Turnovsky, supra note 143.

See Karabanow et al, supra note 34 at 59 wherein one participant in a study stated:

They give you a two hundred dollar ticket while you're trying to make, you know, a couple of bucks for food. You're not going to be paying back that ticket any time soon, you know. It's like yeah, in order for me to pay off that ticket, I'm going to have to squeegee even more and I'm just going to rack them up; it just doesn't make any sense. 
itself. As discussed, deference to one order has not worked and has not brought harmony to public spaces.

\section{MOVING From COMPETING RightS TO FINDING COMMONALITY}

Second, beyond shifting the discourse from maintaining a particular order to a discussion about what order may mean in a specific community, using a legal pluralism lens can help courts to shift from a competing rights focus to one of finding commonality between groups. The discourse surrounding how public space is used is sometimes focused on how marginalized persons "chronically occupy" or "monopolize" public spaces "to the exclusion" of other users. ${ }^{183}$ This language is not helpful as it pits different community members against one another and encourages a competing rights framework. In discussing public spaces as excluding non-marginalized persons, the inverse is not considered - namely that marginalized persons will be excluded if the interests of non-marginalized persons are propped up through state regulation. Instead of dealing with the dangerous, deviant, or chaotic, we are dealing with conventional city dwellers. A legal pluralism lens can help courts understand that the supposed indecency on the street is not unique or concerning; that all of us live in some order, whether apparent or not. Instead of focusing on the dichotomy of state law and disorder, we can discuss how to share public space.

\section{CONSIDERING AlL STAKEHOLDERS’ INTERESTS AND USING CONSULTATION MORE}

Judith Butler provides: "The problem is not merely how to include more people within existing norms, but to consider how existing norms allocate recognition differentially. What new norms are possible and how are they wrought? What might be done to produce a more egalitarian set of conditions for recognizability?" 184

Mapping out the different orders that are present in public spaces is not enough. The work of ethnographers should be taken one step further, and stakeholders should be urged to work in a consultative fashion. The concept of order in a particular neighbourhood can be discussed amongst stakeholders as one that is not absolute, but varied, complex, and uneasy. Instead of focusing adherence to state law, discussions can focus on the optimal use of public space for all those interested. For example, Ellickson proposed that a city's "code of conduct" should "vary spatially — from street to street, from park to park, from sidewalk to sidewalk." 185 Taking this concept further, I argue that the order that is aspired to should be crafted with active collaboration with the users of the space rather than imposed by the state or a court. The acceptance of the existence of plural groups with different values should be the foundation of rule making. ${ }^{186}$ Hirst provides:

How might they coexist and yet keep their own values? Certainly, not as at present fighting to come out on top in the representative democratic system and define central state legislation. A possible strategy is by a

$183 \quad$ Ellickson, supra note 25 at 1188; Batty, supra note 1 at para 97.

184 Judith Butler, Frames of War: When is Life Grievable? (London, UK: Verso Press, 2009) at 6. rules would be different for example for private lands and public lands. 
mixture of micro-governance, that is, special zones where different rules apply, and by mutual extraterritoriality, that is, the parallel existence of self-governing communities sharing the same space but applying rules in matters of community concern to their members alone....

This is not an argument against law, it is an argument for less state regulation and more community selfregulation and internal arbitration. Basing modern societies on such self-governing communities of choice would reduce the load of central inspection and rule making. This would check central state rule proliferation and allow different groups to manage their own affairs.... The advent of greater community self-control would in the long term tend to reduce inter-community friction. ${ }^{187}$

Infusing a legal pluralism framework in the realm of remedies would facilitate a different way of interacting with those in our community. Instead of fearing the stranger, we can engage with people in a dignified way. One scholar recognizes the effectiveness of "selfhelp" defences against people on the street by "declining to give alms" and even "avoiding eye contact after being accosted; coldly staring back; frowning; speaking reprovingly; pushing the extended palm away; spraying mace; and throwing a punch." ${ }^{188}$ Encouraging this kind of interaction does not foster an atmosphere of community. By using a legal pluralism lens, we can encourage the courts to think about how dignity of all members of the community can be promoted. Nora Jacobson finds that social dignity can be generated in individual encounters and that "every human interaction holds the potential to be a dignity encounter — an interaction in which social dignity comes to the fore and is either promoted or violated." ${ }^{189}$ Jacobson argues we want to encourage dignity promotion for two reasons: first, it benefits personhood; and second, it advances autonomy, status, and citizenship. ${ }^{190}$

Using a legal pluralism frame may help the community see how the existence of informal orders promote dignity amongst marginalized persons in public spaces. Duneier writes:

I found strong evidence for the rehabilitative forces of sidewalk life in the self-respect these men maintained as they sold their scavenged magazines and did complex work, and in the interactions with customers that I observed. This was also apparent through the lens of Marvin's deep and caring relationships with Ron, Mudrick, and others as a "mentor" in the structure of sidewalk life. These effects are not surprising when seen in the framework of a long-standing tradition of research on the relationship between work and

Come communities exist already this way: the Danes tolerating the anarchist enclave of Christiania in Copenhagen; gay villages in various cities; and zones allowing prostitution and soft drug use in the Netherlands. Ellickson, supra note 25 at 1195; see also Brandt J Goldstein, "Panhandlers at Yale: A Case Study in the Limits of Law” (1993) 27:2 Ind L Rev 295 at 325-26. International Health and Human Rights. Jacobson relies upon a "grounded theory" which involves considering the experience of persons involved. Dignity violations are more likely when one actor is in a position of vulnerability and the other is in a position of antipathy and when one actor has more power, authority, knowledge, wealth or strength than the other. Ibid. 
personality, and specifically job conditions and psychological functioning. This research demonstrates the importance of opportunities for self-direction in psychological well-being. ${ }^{191}$

Finally, the courts are not strangers to creative remedies. As we have seen in DoucetBoudreau and Abdelrazik, the courts issued remedies under section 24(1) of the Charter that included supervising parties in meeting Charter obligations, consultation between parties, and requiring parties to report back to the court within set timelines. ${ }^{192}$

Seeking more resilient remedies to ongoing conflicts in public spaces involves not only the mapping of orders that exist, but also asking how various interests can be accommodated. Courts should look for remedies that include more consultation, and act as facilitators between community members to help them answer for themselves how common space can be shared.

\section{DANGERS IN RECOGNIZING INFORMAL ORDERS?}

Some scholars assert that giving credence to norms outside of state regulation may be exposing marginalized persons to risks to their health and safety. Hirst however argues: "Much health and safety, environmental protection and public health legislation exists because the state tries to compensate for bodies, like companies, in which affected interests have no say and over which there is no countervailing power." ${ }^{193}$ Localized regulation may provide protection as long as there is education, and the ability to make different choices. ${ }^{194}$ As Turnovsky found, some preferred the informal to the formal centres because of the control they have to negotiate conditions of work. ${ }^{195}$

Further, to mitigate risks, scholars working in developing regions of the world suggest preconditions to not only recognizing but incorporating pluralism as a means to create order. Patrick McAuslan suggests that normative orders should not contradict certain goals associated with protecting human rights. ${ }^{196}$ He suggests participatory community planning replace top-down master planning. ${ }^{197}$ When recognizing normative orders, we can set them against benchmarks. ${ }^{198}$

Duneier, supra note 78 at 63; Bender, supra note 138 at 6: there “exists street family phenomenon” amongst binners where individuals "who have been binning and living on the street for extended periods develop close ties with similar like minded individuals, resulting in a fictive kin relationship"; Turnovsky, supra note 143 at 125: The men at la parada preferred their social ties to the potential opportunities in formal hiring centres. The social ties were formed through common language, ethnicity, and experience. The continued visits to the site went beyond economic needs.

Doucet-Boudreau v Nova Scotia (Minister of Education), 2003 SCC 62, [2003] 3 SCR 3 [DoucetBoudreau]; Abdelrazik v Canada (Minister of Foreign Affairs), 2009 FC 580, [2010] 1 FCR 267 [Abdelrazik].

Hirst, supra note 77 at 292.

Ibid; Merry, supra note 86 at 882 (the ability to forum shop).

Turnovsky, supra note 143 at 125-26.

Patrick McAuslan, “Legal Pluralism as a Policy Option: Is it Desirable? Is it Doable?” in Land Rights for African Development: From Knowledge to Action (Papers delivered at the workshop of the Drylands Development Center and the International Land Coalition, 31 October - 3 November 2005) at 9, online: $<$ www.capri.cgiar.org/Cbrief_land.pdf $>$.

Ibid.

ICHRP, supra note 169 at 115-57 (one example of benchmarks we can use is provided by the ICHRP). 
Second, while some engage in offensive or dangerous behaviour, we must be careful not to essentialize all marginalized persons because of behaviour of a few. Indeed, some offensive and dangerous acts are carried out by persons who use the public space differently than marginalized persons. For example, hundreds engaged in violent activity against persons and property in Vancouver's downtown core following the final game of the Stanley Cup in June 2011. ${ }^{199}$

\section{A PROMising Venue: SECtion 24(1) OF THE CHARTER AS A Vehicle to INFUSE LEgal PluRALISM IN REMEDIES}

How can we infuse a legal pluralism lens into court or legally structured remedies? This article does not purport to provide an exhaustive list of ways in which legal pluralism can be deployed but offers one suggestion as a case study. A promising venue for a legal pluralist approach for solving conflicts in public spaces is section 24(1) of the Charter. This provision will be used as a platform upon which we can demonstrate that a legal pluralist lens can lead to more efficient and sustainable resolutions to conflicts in public spaces. As many of the conflicts arising between marginalized persons and other community members in public space involve the Charter, we can look to the Charter's remedial powers itself as a place to start. The Charter's remedy clause states: “Anyone whose rights or freedoms, as guaranteed by this Charter, have been infringed or denied may apply to a court of competent jurisdiction to obtain such remedy as the court considers appropriate and just in the circumstances.”200

This remedy clause allows a court to go beyond declaring the law is invalid, and provide a "personal remedy" allowing the court to explore a wide range of remedies. ${ }^{201}$ While the courts have traditionally preferred a limited judicial role in issuing remedies by giving declaratory relief, there are precedents where courts have crafted more creative remedies under section 24(1) of the Charter. For example, in New Brunswick v. G. (J.), the court fashioned an affirmative remedy by ordering the province to fund counsel for an indigent litigant. ${ }^{202}$ In Lavoie v. Nova Scotia, a trial court offered a structural remedy where detailed mandatory orders were designed "to determine whether there were grounds for a final remedy of a francophone school." ${ }^{203}$ In R. v. O'Connor, the Supreme Court of Canada acknowledged the flexibility courts have in finding remedies under the Charter: "It is important to recognize that the Charter has now put into judges' hands a scalpel instead of an axe: a tool that may fashion, more carefully than ever, solutions taking into account the sometimes complementary and sometimes opposing concerns of fairness to the individual, societal interests, and the integrity of the judicial system.”204

See e.g. CBC News, "Vancouver police arrest more than 100 in riot” (16 June 2011), online: <www.cbc. ca/news/canada/british-columbia/story/2011/06/16/bc-riot-thursday.html>.

Charter, supra note 14, s 24(1).

Peter W Hogg, Constitutional Law of Canada (Toronto: Carswell, 2011) at 40.27, 40.35. Hogg finds that there is no limitation in the phrase "such remedy as the court considers appropriate and just in the circumstances.”

203 Lavoie v Nova Scotia (Attorney General) (1988), 84 NSR (2d) 387 (SC). While the Court of Appeal overturned the trial decision and relied upon declaratory relief, the Court did provide that it was available in case the province failed to comply with its judgment. 
As well in Dunedin, the Supreme Court of Canada provided:

[Section] 24(1), like all Charter provisions, commands a broad and purposive interpretation. This section forms a vital part of the Charter, and must be construed generously, in a manner that best ensures the attainment of its objects.... Moreover, it is remedial, and hence benefits from the general rule of statutory interpretation that accords remedial statutes a "large and liberal" interpretation.... Finally, and most importantly, the language of this provision appears to confer the widest possible discretion on a court to craft remedies for violations of Charter rights. In Mills, McIntyre J. observed at p. 965 that "[i]t is difficult to imagine language which could give the court a wider and less fettered discretion”. This broad remedial mandate for s. 24(1) should not be frustrated by a "[n]arrow and technical” reading of the provision. ${ }^{205}$

Further, in Doucet-Boudreau, the court of first instance directed the province to build schools and provide programs by certain deadlines. ${ }^{206}$ The issue of remedies reached the Supreme Court of Canada and in deciding how far a court can go in creating remedies under section 24(1) of the Charter, the Court noted it is "well accepted that the Charter should be given a generous and expansive interpretation and not a narrow, technical, or legalistic one." 207 The Court used a "purposive interpretation" to find that section 24(1) should be interpreted to provide a "full, effective and meaningful remedy for Charter violations" allowing courts to "craft responsive" and "effective" remedies ${ }^{208}$ declining to define strict parameters under which remedies should be granted. ${ }^{209}$

Finally, the case of Abdelrazik also provides an apt example of how remedial powers can be used in unconventional ways. ${ }^{210}$ In finding that Abdelrazik's Charter rights were violated when he was unable to return to Canada from Sudan due to requests for travel documents and assistance for travel arrangements from the Canadian government, ${ }^{211}$ the Federal Court turned to section 24(1) of the Charter to provide a comprehensive remedy that included providing an escort and giving the Court a supervisory role over Abdelrazik's return to Canada under a specified timeline. ${ }^{212}$

All of these cases demonstrate that courts have the capacity to go beyond the simple declaratory remedies that we traditionally see coming from Charter cases. The courts, in these cases, are crafting systemic, detailed remedies that are not arbitrary or unrelated to the breaches that have occurred. More importantly, the remedies are crafted with the intention of meeting the interests of the litigants involved.

$R v 974649$ Ontario Inc, 2001 SCC 81, [2001] 3 SCR 575 at para 18 [Dunedin]. In Mills v The Queen, [1986] 1 SCR 863 at 965 , McIntrye J stated:

What remedies are available when an application under s. 24(1) of the Charter succeeds? Section

24(1) again is silent on the question. It merely provides that the appellant may obtain such remedy

as the court considers "appropriate and just in the circumstances". It is difficult to imagine language which could give the court a wider and less fettered discretion. It is impossible to reduce this wide discretion to some sort of binding formula for general application in all cases, and it is not for appellate courts to pre-empt or cut down this wide discretion.

Ibid at para 23.

Ibid at para 25.

Ibid at paras 54-59. The Court did provide some principles to guide courts on how to fashion remedies. Abdelrazik, supra note 192.

Ibid. For a general overview of the facts of the case see paras 13-33.

Ibid at paras 166-69. 
Many of the cases above however, do not deal with conflicts that arise in public spaces and therefore do not deal with conflicts between multiple parties, but are rather binary conflicts between an individual or group, and the state. Could such remedies be crafted in cases dealing with conflicts in public spaces, allowing for evidence revealing a legal pluralist lens to influence what remedies should be given? The alternative is to resort to the traditional declaratory relief, which leaves much to be desired. An apt example is the Khadr II case. ${ }^{213}$ The Supreme Court of Canada found that the lower courts erred in ordering the government to repatriate Omar Khadr, a Canadian citizen detained at Guantanamo Bay, Cuba, finding instead that declaratory relief is sufficient. ${ }^{214} \mathrm{~A}$ few months following the decision of the Supreme Court however, Khadr had to return to the Federal Court to file two applications, again asking for remedies to order the government to ask for his repatriation. The Court did fashion a remedy that included timelines for the parties to exchange information about potential remedies. ${ }^{215}$ Many litigants have to return to court after they have "won" declaratory relief in order to obtain more potent remedies. ${ }^{216}$

While there have been some lost opportunities on the part of the courts to fashion similarly creative remedies in cases involving conflict in public spaces, this does not bar the move towards the use of such remedies in the future. Indeed, in the case of Adams, the Court acknowledged that finding a remedy in this case was particularly difficult and simply declared the impugned bylaws as violating the Charter. ${ }^{217}$ Here, the Court missed an opportunity to come up with a creative way to deal with an ongoing conflict. In practical terms, the Court recognized the right to sleep in a cardboard box and missed an opportunity to engage with the parties on how to deal with future conflicts in Cridge Park. Similarly in the case of Batty, the Court used a competing rights approach to side with one group's use of public space over another part of the community. ${ }^{218}$ This case was a missed opportunity for the Court to craft a remedy that would force all members of the community to face headon the questions the judgment begins with, "How do we live together in a community? How do we share common space?"219

These judicial setbacks should not deter future litigants from proposing plans and remedies that encourage the facilitation of a remedy founded in the interests of everyone involved, creating venues for consultation, discussion, and creativity in ensuring that conflicts do not arise again. Further, Kent Roach writes there is no need to worry that a court will dictate the outcome of a community plan on how to live together. Rather the court may just be a facilitator or a mediator creating the structure by which a plan can be founded:

Canada (Prime Minister) v Khadr, 2010 SCC 3, [2010] 1 SCR 44 [Khadr II]. Ibid at para 39.

Khadr v Canada (Prime Minister), 2010 FC 715, [2010] 4 FCR 36 at paras 31-32. These applications were the result of public statements made by the government that it would not seek the repatriation of Khadr following the Supreme Court ruling.

See e.g. Little Sisters Book and Art Emporium v Canada (Minister of Justice), 2000 SCC 69, [2000] 2 SCR 1120; Kent Roach, "Remedial Consensus and Dialogue Under the Charter: General Declarations and Delayed Declarations of Invalidity" (2002) 35:2 UBC L Rev 211 at 239. Roach finds that in some cases it would be more equitable and efficient for the court to retain jurisdiction over the matter or created remedial structures or detailed injunctions as opposed to general declarations.

Adams, supra note 1 at paras 132, 156.

Batty, supra note 1 at paras 14-15.

Ibid at para 1. 
Even if judges were willing to do so, they cannot dictate all the details of compliance with the Charter. It may often be better for governments, in consultation with the affected groups, to devise their own solutions for constitutional problems. Immediate declarations may not be feasible where the implication of the court's ruling requires the introduction of new governmental services. The use of general declarations and delayed declarations of invalidity give governments time and flexibility to tailor their precise response to Charter cases. This allows governments to respond to dynamic conditions and consult those affected by the decision, including those who are supposed to benefit from the decision. ${ }^{220}$

In asking for such remedies, help from legal pluralists may be enlisted to show that there may be more gained for increased understanding of the "order" in our public spaces and common ground amongst those using that space. Just as litigants in Adams, ${ }^{221}$ Insite,${ }^{222}$ and Bedford $^{223}$ deployed research-based evidence to prove Charter rights were infringed, research-based evidence can also be used when discussing what remedies are best for all parties involved. Here, ethnographic research or the work of legal pluralists in public spaces can be harnessed to show that declaratory relief is not enough. Having been successful at showing violations of the Charter, litigants must now do the work to focus on pushing for more creative and research-based remedies.

\section{What DOES THIS MEAN FOR CASH CORNER?}

Employing a legal pluralism framework and mining ethnographic work on informal orders in public spaces can reveal the order that exists on Cash Corner; that order on Cash Corner is not necessarily driven by or dictated by the state. Exposing the rules that provide the frame for Cash Corner's ritualized production may change how others may glance at Cash Corner.

Instead of regulating civic spaces with concerns stemming from fear, we can craft remedies that are aspirations to get along and live in a workable and just society. Marginalized persons engaged in informal economies deem their work as lawful; they see themselves as entrepreneurs and engaging in self-started businesses. ${ }^{224}$ Using a legal pluralism framework can help humanize those frequenting Cash Corner. This approach can aid the courts in thinking about different ways to provide harmony in the community in the long term. Rather than imposing a remedy or choosing a particular interest over another, the courts should be mindful of shifting that discussion to the community itself. ${ }^{225}$ How can the Hotel Arts and Cash Corner co-exist? How can we ensure that public space is welcoming while preserving the dignity of those who depend on Cash Corner?

Roach, supra note 216 at 255 [emphasis added].

Adams, supra note 1 . Research-based evidence about the number of homeless persons, the number of shelter beds, and the dangers of being exposed to the elements without adequate protection was instrumental in finding the Charter was violated.

Canada (Attorney General) v PHS Community Services Society, 2011 SCC 44, [2011] 3 SCR 134 [Insite]. Litigants in this case provided research about drug users in general and drug users using the supervised injection site.

Bedford, supra note 1. Litigants in this case tendered expert evidence on the social, political, and economic dimensions of prostitution in Canada and evidence from other legal contexts in several foreign jurisdictions leading to findings of Charter violations.

See Duneier, supra note 78 at 79; Bender, supra note 138 at 11; Turnovsky, supra note 143 at 122-30. This article does not presuppose that there is a certain endpoint or goal that should be achieved. In some instances, the plurality of orders may diminish if community norms are incorporated by the state; see e.g. Julia Eckert, "From Subjects to Citizens: Legalism from Below and the Homgenisation of the Legal Sphere” (2006) 53-54 J Leg Pluralism \& Unofficial L 45 at 71-71 (the authors do does not make any statement as to whether this is desirable or not). 


\section{Conclusion}

Legal pluralists remind us that law can be defined in local encounters. ${ }^{226}$ The capacity of our courts to affect social relationships depends on how they respond to the problems that come to them. The courts are increasingly being asked by marginalized communities to mediate conflicts arising in public spaces. In finding remedies, the courts should take guidance from ethnographic research using a legal pluralism lens. Litigants should provide courts with a mapping of the normative orders that exist in public spaces to help them understand marginalized persons. Litigants should also ask for remedies that involve consultation with marginalized communities. Courts should not simply defer to a competing rights framework or to declaratory relief, but look at creative ways to bring the community together to answer: how do we share common space? 